\title{
Persatuan dan Kesatuan Bangsa \\ Dalam Menghadapi Pandemi Covid-19
}

\author{
Ramadhan Yusuf Firdhaus \\ IIK STRADA INDONESIA
}

yframa@gmail.com

\begin{abstract}
Abstrak
Persatuan dan kesatuan mengandung arti bersatunya macam-macam corak yang beraneka ragam menjadi satu kebulatan yang utuh dan serasi. Menurut Kamus Besar Bahasa Indonesia (KBBI) edisi keempat, persatuan adalah gabungan (ikatan, kumpulan dan sebagainya) beberapa bagian yang sudah bersatu, perserikatan, serikat. Sementara pengertian kesatuan berarti perihal satu, keesaan, sifat tunggal, satuan. Virus Corona atau severe acute respiratory syndrome coronavirus 2 (SARS-CoV-2) adalah virus yang menyerang sistem pernapasan. Penyakit karena infeksi virus ini disebut Covid-19. Virus Corona bisa menyebabkan gangguan ringan pada sistem pernapasan, infeksi paru-paru yang berat, hingga kematian. Namun masih ada beberapa masyarakat yang masih kurang kesadaran tentang pentingnya arti persatuan dan kesatuan dalam menjaga kesehatan bersama dengan mentaati beberapa peraturan pemerintah . Segala upaya yang dilakukan pemerintah adalah untuk mengurangi angka kematian yang terjadi karena pandemi , pada akhirnya berhasil atau tidaknya mengatasi pandemi Covid-19 akan sangat tergantung dari usaha perseorangan membangun daya tahan tubuh yang pada hakikatnya merupakan ketahanan perseorangan sebagai titik awal membangun ketahanan nasional.
\end{abstract}

Kata Kunci : Persatuan Kesatuan, Pandemi, Covid-19

\begin{abstract}
Abstrac
Unity and unity mean the unity of various patterns into a whole and harmonious roundness. According to the fourth edition of the Great Dictionary of Indonesian (KBBI), unity is a combination (bond, group and so on) several parts that have been united, unions, unions. While the notion of unity means one thing, oneness, single nature, unit. Coronavirus or severe acute respiratory syndrome coronavirus 2 (SARS$\mathrm{CoV}-2)$ is a virus that attacks the respiratory system. The disease due to this viral infection is called Covid19. Corona virus can cause mild disruption of the respiratory system, severe lung infections, to death. But there are still some people who still lack awareness about the importance of unity and unity in maintaining health along with obeying some government regulations. All efforts made by the government is to reduce the death
\end{abstract}


rate that occurs due to pandemics, ultimately succeeding or not overcoming the Covid-19 pandemic will depend heavily on individual efforts to build endurance which is essentially individual resilience as a staring point for building national resilience.

\section{Keywords: Unity, Pandemic, Covid-19}

\section{A. Latar Belakang}

Menurut Kamus Besar Bahasa Indonesia (KBBI) edisi keempat, persatuan adalah gabungan (ikatan, kumpulan dan sebagainya) beberapa bagian yang sudah bersatu, perserikatan, serikat. Sementara pengertian kesatuan berarti perihal satu, keesaan, sifat tunggal, satuan.

Arti dari kesatuan dan persatuan berasal dari dua kata, yaitu:

\section{Persatuan}

Persatuan berasal dari kata 'satu' yang berarti utuh dan tidak terpecah-belah. Arti lebih luasnya, yaitu berkumpulnya macam-macam corak dari berbagai kalangan, ras, budaya, dan adat istiadat dalam masyarakat yang bersatu dengan serasi.

\section{Kesatuan}

Kesatuan merupakan hasil dari persatuan yang telah menjadi utuh. Hal ini dilakukan untuk terhindar dari disintegrasi, maka sangat dibutuhkan persatuan di Indonesia.

Walau istilah persatuan dan kesatuan saling bersinggungan, keduanya memiliki suatu perbedaan. Persatuan merupakan suatu proses dalam keadaan membentuk masyarakat untuk bersatu, sementara kesatuan merupakan wujud bersatunya masyarakat yang sudah terbentuk.

Persatuan dan kesatuan bangsa merupakan suatu kondisi dan cara terbaik untuk mencapai tujuan bersama. Persatuan dan kesatuan menjadi satu senjata paling ampuh agar tetap utuh .

Indonesia, sebagai negara yang mempunyai banyak keberagaman dan perbedaan, perlu mempunyai persatuan dan kesatuan. Keberagaman yang terdapat di Indonesia, antara lain agama, suku, etnis, budaya bahasa, maupun adat istiadat.

Itulah mengapa, penting memiliki sikap persatuan dan kesatuan antar sesama masyarakat demi menjaga keutuhan bangsa dan negara Indonesia. Tanpa adanya rasa persatuan dan kesatuan, bangsa Indonesia akan mudah terpecah terpecah belah. 
Persatuan dan Kesatuan Bangsa Indonesia diwujudkan dalam semboyan pada lambang Negara Republik Indonesia yaitu "BHINNEKA TUNGGAL IKA" yang keberadaannya berdasarkan pada PP No. 66 Tahun 1951, mengandung arti beraneka tetapi satu (Ensiklopedia Umum, 1977).

Semboyan tersebut menurut Supomo, menggambarkan gagasan dasar yaitu menghubungkan daerah-daerah dan suku-suku bangsa di seluruh Nusantara menjadi Kesatuan Raya (ST Munadjat D, 1928). Bila dirujuk kepada asalnya yaitu Kitab Sutasoma yang ditulis oleh Empu Tantular abad ke XIV, ternyata semboyan tersebut merupakan seloka yang menekankan tentang pentingnya kerukunan antar umat dari agama yang berbeda pada waktu itu adalah agama Siwa dan Budha. Lengkapnya Bhinneka Tunggal Ika berbunyi Bhinneka Tunggal Ika Tanhana Dharmma Mangrva. Hal tersebut merupakan kondisi dan tujuan kehidupan yang ideal dalam lingkungan masyarakat yang serba majemuk.

Keberagaman atau kehidupan dalam lingkungan majemuk bersifat alami dan merupakan sumber kekayaan budaya bangsa. Setiap perwujudan mengandung ciri-ciri tertentu yang membedakannya dari perwujudan yang lain, tidak mungkin satu perwujudan mengandung semua ciri yang ada, karena bila hal itu terjadi maka dia akan menjadi maha sempurna, padahal hanya satu maha sempurna yaitu TUHAN.

Virus Corona atau severe acute respiratory syndrome coronavirus 2 (SARS-CoV-2) adalah virus yang menyerang sistem pernapasan. Penyakit karena infeksi virus ini disebut Covid-19. Virus Corona bisa menyebabkan gangguan ringan pada sistem pernapasan, infeksi paru-paru yang berat, hingga kematian.

Severe acute respiratory syndrome coronavirus 2 (SARS-CoV-2) yang lebih dikenal dengan nama virus Corona adalah jenis baru dari coronavirus yang menular ke manusia. Virus ini bisa menyerang siapa saja, seperti lansia (golongan usia lanjut), orang dewasa, anak-anak, dan bayi, termasuk ibu hamil dan ibu menyusui.

Infeksi virus Corona disebut COVID-19 (Corona Virus Disease 2019) dan pertama kali ditemukan di kota Wuhan, China pada akhir Desember 2019. Virus ini menular dengan sangat cepat dan telah menyebar ke hampir semua negara, termasuk Indonesia, hanya dalam waktu beberapa bulan.

Di era pandemi Covid-19 yang sedang melanda Indonesia sekarang ini menimbulkan tantangantantangan tersendiri bagi pemerintah dan masyarakat Indonesia. Berbagai upaya dilakukan untuk menangani pandemi yang menimbulkan masalah-masalah lainnya yang berujung pada persatuan dan kesatuan bangsa. 


\section{B. Kasus / Masalah}

Masih ada beberapa masyarakat yang masih kurang kesadaran tentang pentingnya arti persatuan dan kesatuan dalam menjaga kesehatan bersama dengan mentaati beberapa peraturan pemerintah .

\section{Tinjauan Pustaka}

Angka kasus corona yang aktif saat ini sudah menurun tak lepas dari peran masyarakat dan pemerintah yang saling bersatu dalam menghadapi pandemi Covid-19. Tetap pegang erat rasa nasionalisme dan tumbuhkan rasa persatuan dan kesatuan agar tidak goyah dengan konflik - konflik yang timbul selama pandemi Covid-19. Meskipun ada beberapa masyarakat yang masih belum paham dan mengerti pentingnya persatuan dalam menghadapi Covid-19.

Adapun beberapa faktor yang mempengaruhi masyarakat kurang menyadari pentingnya persatuan adalah sebagai berikut :

1. Kurangnya upaya untuk dapat saling menghargai satu sama lain antar sesama bangsa yang berlandaskan rasa kemanusiaan sehingga tidak dapat tercapai kehidupan yang serasi dan harmonis.

2. Partisipasi masyarakat yang masih kurang karena tidak semua masyarakat mau dan patuh terhadap protokol kesehatan .

3. Tidak menjalin rasa kekeluargaan, persahabatan, saling tolong menolong, serta nasionalisme antarbangsa yang dapat menjaga persatuan dan kesatuan bangsa dalam mengahadapi pandemi.

\section{Pembahasan}

Di dalam persatuan dan kesatuan bangsa mengandung nilai-nilai positif. Adapun nilai dan manfaat yang ada dalam persatuan dan kesatuan, antara lain:

1. Persatuan dan kesatuan dapat mengatasi semua perbedaan dengan penuh kesabaran dan kesadaran.

2. Persatuan antarwarga negara dapat membuat pembangunan nasional berjalan lancar, aman, baik, dan sesuai harapan.

3. Bangsa Indonesia akan lebih mudah maju dan berkembang dengan menerima perbedaan yang muncul.

4. Akan lebih mudah untuk mencapai tujuan nasional yang tertuang dalam pembukaan UUD 1945 alinea keempat. 
5. Dengan adanya persatuan dan kesatuan, akan tercipta suasana yang aman, damai, dan tenteram dalam negara. Terutama karena adanya sikap toleransi, solidaritas, dan setia kawan di antara warganya.

6. Persatuan dan kesatuan dapat mewujudkan kehidupan yang seimbang, harmonis, serta serasi antarmanusia.

7. Pelaksanaan gotong royong dalam lingkungan sekitar akan berjalan lancar tanpa adanya kendala.

8. Saling menjaga kerukunan dan menjalin silaturahmi antarbangsa

9. Menjaga keutuhan Negara Kesatuan Republik Indonesia (NKRI) supaya tidak mudah terpecah belah oleh orang lain.

10. Akan lebih mudah mengatasi berbagai gangguan baik yang muncul dari dalam maupun dari luar.

Persatuan dan Kesatuan tertulis jelas di dalam Pancasila sila ke-3. Sila tersebut menjadi landasan kita agar menjadi satu dan tidak terpecah belah. Terutama dalam situasi sulit seperti sekarang ini yaitu menghadapi pandemi Covid-19. Dengan menjaga Kesatuan dan Persatuan, bangsa Indonesia akan menjadi bangsa yang kuat menghadapi berbagai macam cobaan termasuk dalam menghadapi cobaan pandemi Covid-19.

Dalam keadaan saat ini, suatu bangsa dituntut untuk menunjukkan nilai-nilai terbaik dari ideologi kebangsaan untuk dapat mengatasi tantangan pandemi Covid-19. Keadaan ini mengandung semua nilainilai kearifan lokal yang terkandung dalam Pancasila, yaitu efektivitas pemerintahan yang berpadu dengan kepercayaan dan kepatuhan rakyat terhadap semua ketentuan yang diterbitkan pemerintah, serta kesadaran pada masyarakat untuk menghubungkan kepentingan perorangan dengan kepentingan masyarakat, yakni dengan menjauhi sikap egosentris yang hanya memikirkan diri sendiri. Hal tersebut dapat diimplementasikan dengan keputusan tetap berada di rumah, tidak bepergian, dan menghindari kerumunan.

\section{E. Kesimpulan}

Proses menanggulangi pandemi Covid-19 yang tidak mudah, membuat pemerintah memberlakukan kebijakan-kebijakan seperti Pemberlakuan Pembatasan Kegiatan Masyarakat (PPKM), isolasi lokal, larangan bepergian, serta pemberian bantuan pada masyarakat yang mengandalkan penghasilan harian. Namun, semua upaya pemerintah berarti banyak jika tidak mendapat dukungan dari semua pihak. Pada akhirnya berhasil atau tidaknya mengatasi pandemi Covid-19 akan sangat tergantung dari usaha perseorangan membangun daya tahan tubuh yang pada hakikatnya merupakan ketahanan perseorangan sebagai titik awal membangun ketahanan nasional. 


\section{Daftar Pustaka}

Cristy, Meri Dame.2021. Virus Corona

https://www.alodokter.com/virus-corona

Mufidah, Hasna Adinda.2021. Persatuan dan Kesatuan

https://www.kompasiana.com/adinda24370/615f5e050101904e120d0a26/persatuan-dan-kesatuan

Widianto, Ari.2020. Makna Persatuan dan Kesatuan

https://www.kompas.com/skola/read/2020/03/06/140000369/makna-persatuan-dan-kesatuan

Nugroho, Fauzan.2021. Pengertian, Makna dan Arti Persatuan Kesatuan

https://www.bola.com/ragam/read/4501280/pengertian-persatuan-dan-kesatuan-makna-manfaat-sertacontohnya-yang-perlu-dipahami 